\title{
Effect of Nitrogen Limitation on Cell Growth, Lipid Accumulation and Gene Expression in Chlorella sorokiniana
}

\author{
Ying Xia $\mathrm{Li}^{{ }^{*}}$, Feng Juan $\mathrm{Zhao}^{2}$ and Dong Dong $\mathrm{Yu}^{3}$ \\ ${ }^{I}$ Marine Science and Engineering College; Qingdao Agricultural University; Qingdao - P.R.China. ${ }^{2}$ Department of \\ Biological Sciences; BinZhou University; Bingzhou - P.R. China. ${ }^{3}$ Huangdao Entry-Exit Inspection and Quarantian \\ Bureau; Qingdao - P.R. China
}

\begin{abstract}
The influence of nitrogen $(N)$ limitation on the cell growth, chlorophyll content, intracellular lipid production and expression levels of two pathway genes in Chlorella sorokiniana was investigated in mixotrophic culture in this study. The maximum biomass concentration of $\mathrm{C}$. sorokiniana cultured in modified BG11 medium containing 3, 6, 9, 12 and $15 \mathrm{mM} \mathrm{N}$ were 1.60, 2.21, 2.74, 3.18 and $3.21 \mathrm{~g} / \mathrm{L}$ of dry cell weight, respectively with maximum specific growth rate of $0.180,0.198,0.201,0.203,0.206$ day-1 during culture with an initial $N$ feed of 3, 6, 9, 12 and 15 $\mathrm{mM}$ in the first eight days, respectively. The maximum lipid content was $51 \%$ with $3 \mathrm{mM} \mathrm{N}$. However, the maximum lipid productivity of $0.00884 \mathrm{~g} \mathrm{L-1}$ day-1 was achieved with $6 \mathrm{mMN}$. Expression levels of accD (heteromeric acetyl-CoA carboxylase beta subunit) and accI (homomeric acetyl-CoA carboxylase) genes in C. sorokiniana were studied by real-time PCR. Increased expression levels of accD reflected the increased lipid content in stationary phase. In contrast, expression of the accl gene always remained low, showing that the gene might not be critical for lipid accumulation.
\end{abstract}

Key words: nitrogen limitation, Chlorella sorokiniana, lipid, Real- time PCR

\section{INTRODUCTION}

With the shortage of fossil fuels and their production of green house gas carbon dioxide upon combustion, it is a pressing mission for humans to find an alternative fuel. Microalgal biodiesel is now receiving considerable attention (Chisti 2007). Microalgal biodiesel is a secondgeneration biofuel, and microalgal lipids may be a more sustainable biodiesel feedstock than crop oils because of their widespread availability and higher lipid yields (Cheng et al. 2009). To achieve high biomass and lipid production, microalgae are cultured in heterotrophic conditions where some organic carbons such as sugars and organic acids are added to serve as carbon sources ( $\mathrm{Xu}$ et al.
2006; Liang et al. 2009). However, the alga culturing in strict heterotrophy is more expensive than in photoautotrophy. Mixotrophic cultivation is not only complement photoautotrophy with organ carbon, but also can reduce the cost of heterotrophic microalgal culture and improve the lipid content (Wan et al. 2011). Hence, the microalga cultured under mixotrophic condition can exhibit higher biomass and lipid content. Microalgae have been frequently cultured in nitrogen deficient media that allows obtaining higher lipid productivity (Liu et al. 2012). Limiting nitrogen in the culture medium can induce Chlorella vulgaris to accumulate more total lipid (Chen and Johns 1991).

*Author for correspondence: liyx108@163.com 
Acetyl coenzyme A (Acetyl-CoA) is a key substance of lipid synthesis. Acetyl-CoA carboxylase (ACCase) show crucial role in fatty acid biosynthesis, which can catalyze acetyl-CoA to be converted to malonyl-CoA and to enter the pathway of lipid biosynthesis (Cronan and Waldrop 2002). Many plants contain two forms of ACCase: heteromeric/ bacterial and homomeric/ eukaryotic ACCase. Heteromeric ACCase is the key enzyme for fatty acid synthesis in the chloroplast including four subunits, but only the beta subunit (accD) is synthesized in the chloroplast. The expression of accD gene in the chloroplast genome is very important to the levels of heteromeric ACCase (Nakkaew et al. 2008). Homomeric/ eukaryotic ACCase, encoded by acc1 gene is composed of a single polypeptide and important for the synthesis of long-chain fatty acids, flavonoids, and anthocyanins in the cytosol (Sasaki and Nagano 2004).

The genus Chlorella is the oldest commercial application of microalgae and can be grown in photo/mixo/heterotrophic mode of culture. $C$. sorokiniana is a promising freshwater non-motile unicellular alga, accumulating high amounts of lipids and proteins (Wan et al. 2011). C. sorokiniana is one of potential microalgal species used for the lipid production. In this study, the effect of nitrogen limitation on the growth, lipid content and expression levels of three pathway genes in $C$. sorokiniana was investigated. Firstly, the effect of nitrogen concentration on the cell growth, chlorophyll content and lipid productivity was examined. Secondly, accD and accI gene expression level in this alga under nitrogenlimited culture conditions was assessed using realtime PCR in mixotrophic culture.

\section{MATERIAL AND METHODS}

\section{Strain and Culturing Conditions}

The strain C. sorokiniana was purchased from the Freshwater Algae Culture Collection of the Institute of Hydrobiology in Wuhan, China. The culture medium was modified BG-11 in which the concentration of $\mathrm{NaNO}_{3}$ was adjusted to $3,6,9$, $12,15 \mathrm{Mmol} \mathrm{L}^{-1}$, and $25 \mathrm{~g} . \mathrm{L}^{-1}$ glucose was added. The components of basal culture medium were as follows (mg/L): $40 \mathrm{~K}_{2} \mathrm{HPO}_{4}, 700 \mathrm{MgSO}_{4} .7 \mathrm{H}_{2} \mathrm{O}$, $36 \mathrm{CaCl}_{2} \cdot \mathrm{H}_{2} \mathrm{O}, 6$ citric acid, 6 Ferric ammonium citrate, 0.1 EDTANa $2,20 \mathrm{Na}_{2} \mathrm{CO}_{3}, \quad 1$ trace containing (g/L): $2.86 \mathrm{H}_{3} \mathrm{BO}, 1.86 \mathrm{MnCl}_{2} \cdot \mathrm{H}_{2} \mathrm{O}$, $\begin{array}{lllll}0.22 & \mathrm{ZnSO}_{4} .7 \mathrm{H}_{2} \mathrm{O}, & 0.08 & \mathrm{CuSO}_{4} .5 \mathrm{H}_{2} \mathrm{O}, & 0.39\end{array}$ $\mathrm{Na}_{2} \mathrm{MoO}_{4} \cdot 2 \mathrm{H}_{2} \mathrm{O}$ and $0.05 \mathrm{Co}\left(\mathrm{NO}_{3}\right)_{2} \cdot 6 \mathrm{H}_{2} \mathrm{O}$. The initial $\mathrm{pH}$ of the medium was adjusted to 7.0. The cultures were incubated at $28^{\circ} \mathrm{C}$ with shaking at $120 \mathrm{rpm}$ under $20 \mu \mathrm{mol}$ photons. $\mathrm{m}^{-2} \cdot \mathrm{s}^{-1}$ illuminations through cool-white fluorescent lamps with a photoperiod of $12 \mathrm{~h}$ light/dark. This experiment was conducted in three replicate. For nitrogen limitation, the cells were washed three times with sterilized distilled water and suspended in a nitrogen-limitation medium.

\section{Determination of growth rate and Lipid Content}

The specific growth rates $(\mu)$ was calculated using the following equation: $\mu=\left(\operatorname{InN}_{t}-I n N_{0}\right) / t$ where $\mathrm{N}_{0}$ was the initial dry weight and $\mathrm{N}_{\mathrm{t}}$ was the dry weight at time $t$.

For lipid analysis, cells were harvested using centrifugation at $10000 \mathrm{~g}$ for $10 \mathrm{~min}$ and the pellets were dried at $60^{\circ} \mathrm{C}$ for overnight. The dried microalgae samples $(0.2 \mathrm{~g})$ were extracted with 50 $\mathrm{mL}$ of chloroform-methanol $(2: 1, v / v)$ over $24 \mathrm{~h}$ and sonicated at room temperature with a sonicator for $30 \mathrm{~min}(60 \mathrm{~W}, 6 \mathrm{~s}$ interval). Then, the suspension was filtered and the filtrate was washed two times with a $\mathrm{KCl}$ solution. The lower liquid was transferred into a pre-weighed glass vial. The chloroform-methanol solution was evaporated to dryness at $40{ }^{\circ} \mathrm{C}$ under vacuum. The lipid content was measured and calculated using the following equation: $\mathrm{Y}(\%)=\mathrm{W}_{\mathrm{L}} / \mathrm{W}_{\mathrm{DA}}$, where $\mathrm{W}_{\mathrm{L}}$ and $\mathrm{W}_{\mathrm{DA}}$ were the weights of the extracted lipid and the dry algae biomass, respectively.

\section{Determination of $\mathrm{N}$ Concentration and Chlorophyll Content}

The $\mathrm{N}$ concentrations were detected by a UV spectrophotometer at 220 and $275 \mathrm{~nm}$. Two milliliters microalgal cell suspension was centrifuged at $10,000 \mathrm{~g}$ for $5 \mathrm{~min}$ and the cell sediments were resuspended in $5.0 \mathrm{~mL} 95 \%(\mathrm{v} / \mathrm{v})$ ethanol in dark for $12 \mathrm{~h}$. Afterwards the cell suspension was centrifuged at $10,000 \mathrm{~g}$ for 10 min. The absorbance (A) of the supernatant was measured at 665 and $649 \mathrm{~nm}$ using a spectrophotometer. The concentrations of chlorophyll were calculated by the following equations:

$\mathrm{C}\left({ }_{\mathrm{a}+\mathrm{b}}\right)(\mathrm{mg} / \mathrm{L})=1.44 \mathrm{~A}_{665}+24.93 \mathrm{~A}_{652}$ 


\section{Statistical Analysis}

All the experiments were conducted in triplicate treatments unless otherwise stated. Data analyses were done by using the SPSS 10. One-way Analysis of Variance (ANOVA) was used and Least Significant Differences were calculated at $\mathrm{P}=0.05$ (LSD0.05).

\section{Total RNA extraction and cDNA synthesis}

According to the growth curves of $C$. sorokiniana under various $\mathrm{N}$ concentrations, samples were collected in logarithmic phase (fifth day) and stationary phase (tenth day). Total RNA was isolated and purified from $C$. sorokiniana cultured in medium supplemented with 25 g.L $\mathrm{L}^{-1}$ of sterilized glucose with RNAprep Pure Plant Kit (Tiangen, China) according to the manufacturer's instructions. Total RNAwas quantified at $\mathrm{OD}_{260}$ and $\mathrm{OD}_{280}$, and the integrity of total RNA was checked by $1.5 \%$ agarose gel electrophoresis and ethidium bromide staining. To confirm the removal of genomic DNA from total RNA, amplification of the control gene (18S rRNA) was performed using RNA as PCR templates. Total RNA served as the template to synthesize cDNA with RevertAid ${ }^{\mathrm{TM}} \mathrm{H}$ Minus First Strand cDNA Synthesis Kit (Fermentas, China) with random primers.

\section{Real-time PCR assay}

All primer pairs of selected genes are listed in Table 1 . The $18 \mathrm{~S}$ rRNA gene of $C$. sorokiniana was used as the internal standard. Real-time PCR was performed in an iCycler iQ real-time PCR detection system (Bio-Rad Laboratories, Inc., Hercules, USA) using SYBR ${ }^{\circledR}$ Green real-time PCR Master Mix (Toyobo Co., Ltd., Osaka, Japan) according to the manufacturer's instructions: one cycle of $95{ }^{\circ} \mathrm{C}$ for $30 \mathrm{~s}$ and then 40 cycles of $95^{\circ} \mathrm{C}$ for $15 \mathrm{~s}$ each, followed by $55^{\circ} \mathrm{C}$ for $15 \mathrm{~s}$, and $72{ }^{\circ} \mathrm{C}$ for $30 \mathrm{~s}$. The $25 \mu \mathrm{L}$ reaction solution of real-time PCR was composed of 2.5 $\mu \mathrm{L}$ of cDNA, $0.4 \mu \mathrm{m}$ final concentration of each primer and $12.5 \mu \mathrm{L} 2 \times$ real-time PCR Master Mix. Three biological and three technical replicate were analyzed: Three parallel samples were used for RNA isolation and three parallel real-time PCR analyses were performed for each RNA sample. In order to normalize the amount of transcripts in each sample, the relative abundance of 18S rRNA was also determined as the internal standard. At the completion of each run, melting curves for the amplicons were measured by raising the temperature stepwise by $0.5^{\circ} \mathrm{C}$ from $55^{\circ} \mathrm{C}$ to $95^{\circ} \mathrm{C}$ while monitoring fluorescence. The specificity of the PCR amplification was checked by examining the melting curve for melting temperature ${ }^{\mathrm{TM}}$, its symmetry and the lack of non-specific peaks. The gene expression data was analyzed using the $2^{-\Delta \Delta \mathrm{Ct}}$ method. Different concentrations of purified $18 \mathrm{~S}$ rRNA gene fragments were used to generate the standard curve of real-time PCR.

Table 1 - Primer for real-time PCR detection of expression of genes related to lipid accumulation in Chlorella sorokiniana.

\begin{tabular}{llc}
\hline Gene & Primer sequence & $\begin{array}{c}\text { Length (bp) } \\
\text { of } \\
\text { Production }\end{array}$ \\
\hline$a c c D$ & F:TTTGGTTTGTGCTTCTGGTG & 149 \\
& R:CACCACCAGTTGTTGGAGAA & \\
$a c c l$ & F:TGACCGTGAAAAAGCATCTG & 163 \\
& R:CGACATATTCGCCTGATTGA & \\
$18 S$ & F:CCTGCGGCTTAATTTGACTC & 192 \\
rRNA & R:GCGAACCAACCGTGACTATT & \\
\hline & & \\
\end{tabular}

\section{RESULTS}

\section{The Effect of $\mathbf{N}$ limiatation on the Growth of $C$. sorokiniana}

The growth profiles of $C$. sorokiniana with different $\mathrm{N}$ concentrations in the modified BG-11 medium are shown in Figure 1. The growth of $C$. sorokiniana was significantly and positively correlated with nitrogen concentration in the medium. Evidently, all growth curves showed a similar progression: one day of lag phase and seven to eight days of logarithmic phase, followed by a stationary phase. It took eight days for $C$. sorokiniana to reach stationary phase under initial $\mathrm{N}$ feed 3 and $6 \mathrm{mM}$ and nine days with an initial $\mathrm{N}$ feed of $9 \mathrm{mM}$. It took ten days to reach stationary phase under an initial $\mathrm{N}$ feed of 12 and $15 \mathrm{mM}$. After ten days of culture, a higher initial $\mathrm{N}$ concentration in the medium produced an increased biomass concentration and the highest biomass concentration was $3.210 \mathrm{~g} \mathrm{~L}^{-1}$ with initial $\mathrm{N}$ feed of $15 \mathrm{mM}$, which also produced a specific growth rate of $0.321 \mathrm{day}^{-1}$. The lowest growth rate of 0.200 day $^{-1}$ occurred with initial $\mathrm{N}$ feed of 3 $\mathrm{mM}$. At the end of the culture, $75.86 \%$ of the $\mathrm{N}$ had been removed from the medium with initial $\mathrm{N}$ feed of $15 \mathrm{mM}$. No $\mathrm{N}$ was detected after tenth day for the medium with 3 and $6 \mathrm{mM} \mathrm{N}$ (Table 2). 


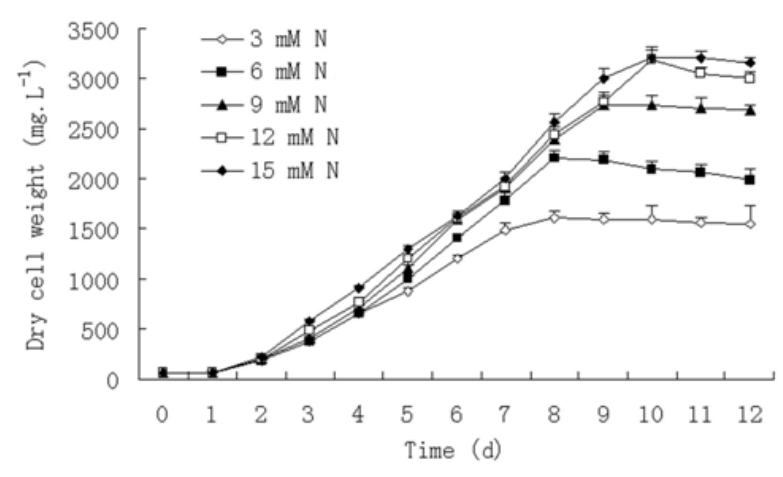

Figure 1 - Typical time-course profiles of cultivated in the modified BG-11medium containing different $\mathrm{N}$ concentrations in Chlorella sorokiniana.

\section{The Effect of $N$ limiatation on the Lipid Content}

The lipid content reached to $51 \%$ of the biomass after ten days of cultivation with initial $\mathrm{N}$ feed of $3 \mathrm{mM}$ in the modified BG-11 medium (Fig. 2). Also, the lipid content with $3 \mathrm{mM} \mathrm{N}$ was more than two times higher than that with $15 \mathrm{mM} \mathrm{N}$, suggesting that excess nitrogen in the medium led to the decrease of the lipid content in the cell.
Notwithstanding, lipid productivity was highest with $6 \mathrm{mM} \mathrm{N}$. The highest total lipid content $(0.51$ $\mathrm{g} / \mathrm{g})$ and lipid yield $(0.884 \mathrm{~g} / \mathrm{L})$ were achieved when cultured with initial $\mathrm{N}$ feed of 3 and $6 \mathrm{mM}$, respectively. Therefore, even though the cells had high lipid content, the biomass concentration was low when nitrogen was limited (initial $\mathrm{N}$ concentration below $3 \mathrm{mM}$ ). The initial $\mathrm{N}$ feed of $6 \mathrm{mM}$ was identified as the critical concentration to achieve high growth rate and high lipid productivity (Table 2 ).

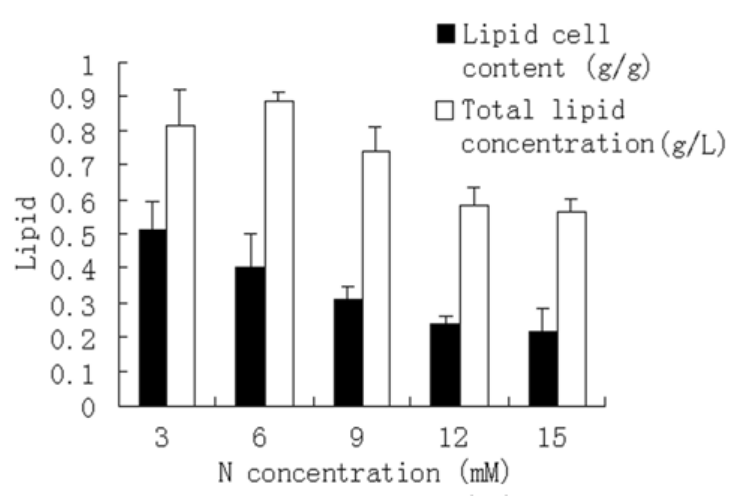

Figure 2 - Lipid productivity in the media of different $\mathrm{N}$ concentrations.

Table 2 - Summary of cell growth, specific growth rate, lipid production and nitrogen consumption results obtained with media with different $\mathrm{N}$ concentrations in Chlorella sorokiniana.

\begin{tabular}{llllll}
\hline & \multicolumn{5}{c}{ N concentration (mM) } \\
\cline { 2 - 6 } & $\mathbf{3}$ & $\mathbf{6}$ & $\mathbf{9}$ & $\mathbf{1 2}$ & $\mathbf{1 5}$ \\
\hline Initial $\mathrm{NaNO}_{3}(\mathrm{mM})$ & 2.88 & 5.91 & 9.21 & 12.43 & 15.74 \\
Residual $\mathrm{NaNO}_{3}(\mathrm{mM})$ & 0 & 0 & 0.5 & 1.7 & 3.8 \\
Maximum biomass concentration $(\mathrm{g} / \mathrm{L})$ & 1.602 & 2.210 & 2.740 & 3.180 & 3.210 \\
Biomass productivity $\left(\mathrm{g} \mathrm{DCW} \mathrm{1}^{-1} . \mathrm{d}^{-1}\right)$ & 0.200 & 0.27 & 0.298 & 0.318 & 0.321 \\
Biomass yield $\left(\mathrm{g} \mathrm{DCW} / \mathrm{g} \mathrm{N}^{-}\right.$ & 39.732 & 26.710 & 22.470 & 21.169 & 20.958 \\
Lipid productivity $\left(\mathrm{g} \mathrm{L}^{-1} . \mathrm{d}^{-1}\right)$ & 0.0817 & 0.0884 & 0.074 & 0.058 & 0.056 \\
\hline
\end{tabular}

The Effect of $N$ limiatation on the $N$ Consumption and Chlorophyll Content

Figure 3A shows the time-course profiles of $\mathrm{N}$ consumption in the cultures with different initial concentrations. The media with 3 and $6 \mathrm{mM}$ initial $\mathrm{N}$ were depleted after four and six days, respectively. Not surprisingly, however, substantial residual $\mathrm{N}$ was detected at the end of culture in media containing 9,15 and $20 \mathrm{mM} \mathrm{N}$ initially. The volumetric contents of chlorophyll in both reached highest on the tenth day (Fig. 3B), while they reached the highest level on the tenth day with initial $\mathrm{N}$ feed of $15 \mathrm{mM}$, which suggested that abundant $\mathrm{N}$ promoted the chlorophyll accumulation in the cells. The maximum chlorophyll content was $3.97 \mathrm{mg} \mathrm{L}^{-1}$.
The Effect of $\mathbf{N}$ limiatation on the expression of accD and accI

The expression levels of two different genes (accD and accI) in C. sorokiniana were studied under various $\mathrm{N}$ concentrations by real-time PCR during logarithmic and stationary phase (Fig. 4). Expression levels of accD increased dramatically from the logarithmic phase to stationary phase at all $\mathrm{N}$ concentrations and decreased with the increase of $\mathrm{N}$ concentration (A). The expression level of accD in stationary phase was very low at all $\mathrm{N}$ concentrations. In contrast, the expression of the acc1 gene was very low at all $\mathrm{N}$ levels and the maximum value was only 0.15 (B). Those results suggested that this gene might not be critical for lipid accumulation. 

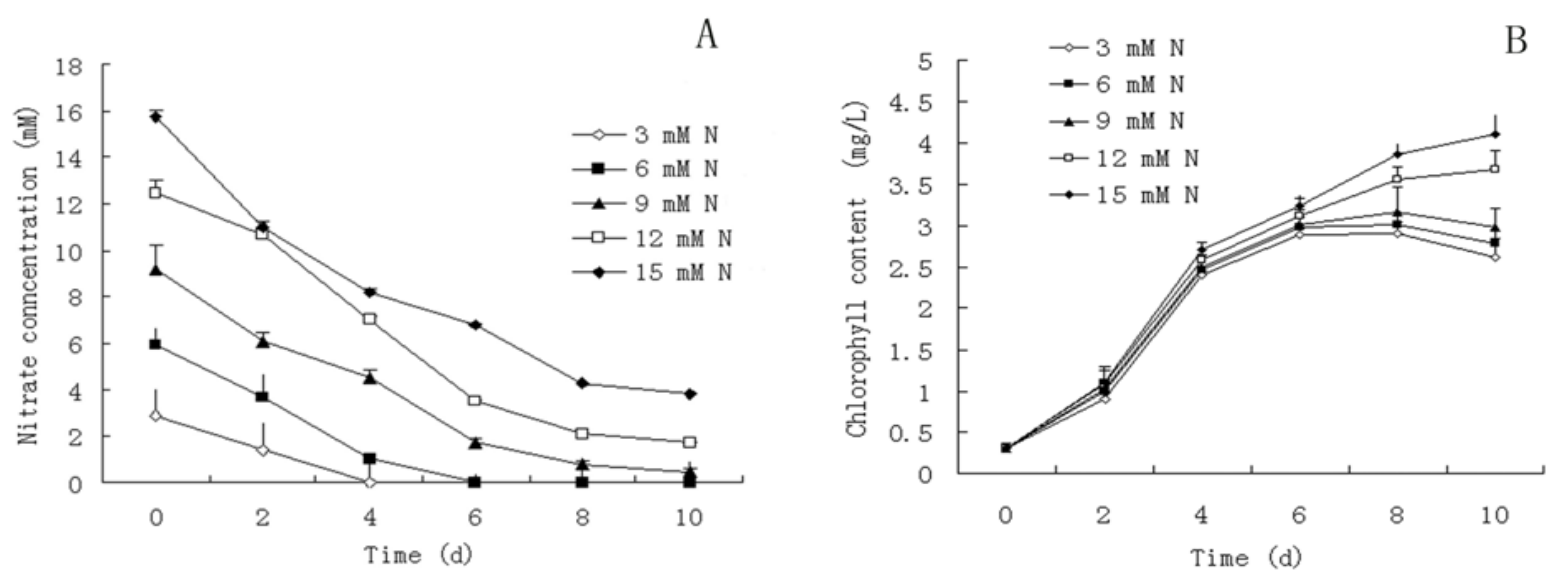

Figure 3 - Nitrogen consumption (A) and Chlorophyll content (B) in the media of different N concentrations.
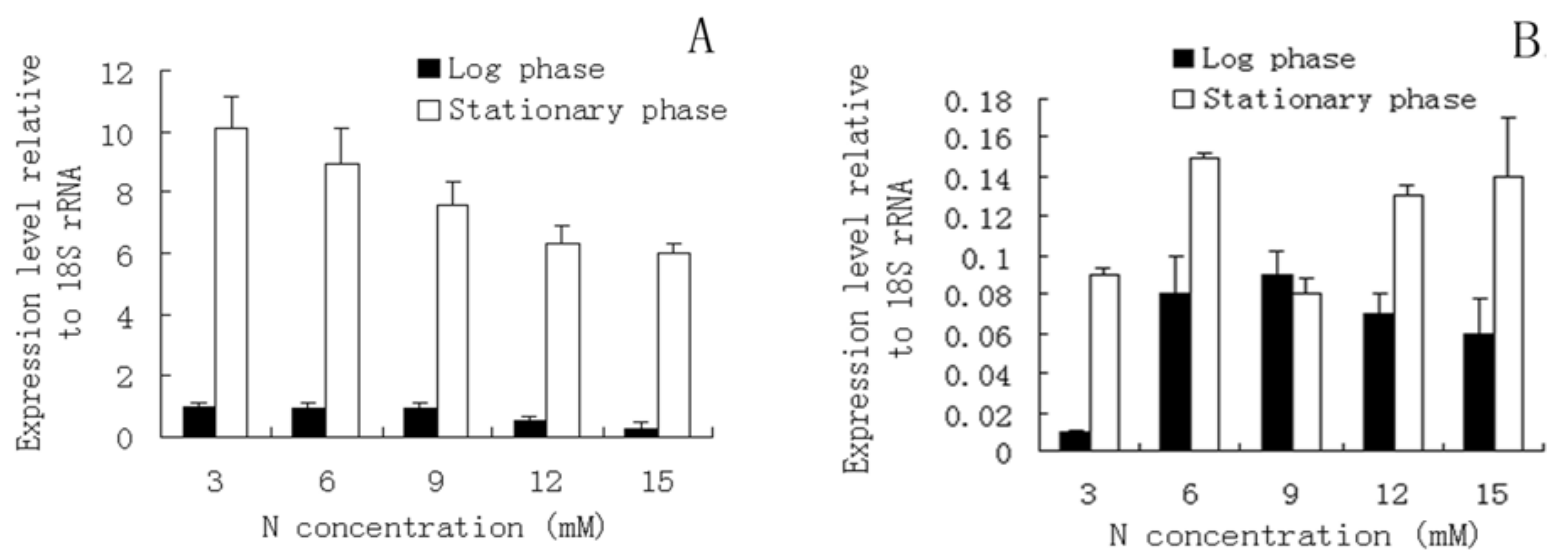

Figure 4 - Quantification of the expression of pathway genes, $\operatorname{accD}(\mathrm{A})$ and $\operatorname{acc} 1(\mathrm{~B})$ related with lipid synthesis in Chlorella sorokiniana with different $\mathrm{N}$ concentrations, where the results were normalized against the control gene (18SrRNA gene), to correct sample-to-sample variation.

\section{DISCUSSION}

The biochemical composition of microalgae can be affected by changing the physical and chemical parameters of the culture medium including nitrogen limitation (Huang et al. 2013). Nitrogen limitation is a severe stress condition for all the organisms, as nitrogen is a major constituent of proteins and nucleic acids. In this study, limiting $\mathrm{N}$ led to accumulation of lipid. Nitrogen limitation in Isochrysis galbana culture can increase the intracellular content of fatty acid and active diacylglycerol acyltransferase, which converts fatty acid to triglyceride (Sukenik and Wahnon 1991). This might be the main reason for shifting from growth to high lipid content in Chlorella cultures on the stationary phase. Therefore, a low $\mathrm{N}$ concentration increased the total lipid content.
The results also showed that different $\mathrm{N}$ concentrations influenced cell growth and lipid productivity. An initial $\mathrm{N}$ feed of $6 \mathrm{mM}$ was identified as the critical concentration to achieve a high growth rate and high lipid productivity. Therefore, higher lipid productivity could also be achieved by two-step-culture method. The microalage were cultured in a mediun with sufficient $\mathrm{N}$ to achieve a higher biomass, then was transferred to a $\mathrm{N}$-limited medium to attain higher lipid.

Comparing the results from Figures 1 and $3 \mathrm{~A}$, it was obvious that the cell growth continued after nitrogen source was exhausted from the culture when $\mathrm{N}$ concentration was 3 or $6 \mathrm{mM}$. The reason might be that nitrogen pools such as chlorophyll molecules were consumed to support the cell growth after nitrogen exhaustion ( $\mathrm{Li}$ et al. 2008). 
Therefore, the chlorophyll content of algal content cultured in media with lower $\mathrm{N}$ concentration was low.

The expression of accD in the chloroplast was very important to the levels of heteromeric ACCase (Nakkaew et al. 2008) and was upregulated from the logarithmic to stationary phase along with the increase of lipid content in $C$. sorokiniana with $\mathrm{N}$ limitation. The result also showed that heteromeric ACCase was one of the key enzymes required for lipid biosynthesis. The expression levels of accD was low in logarithmic phase in all the culture. Two reasons might be responsible for it. Firstly, in the lipid biosynthetic pathway, acetyl-CoA was first converted to malonyl-CoA in a step catalyzed by acetyl-CoA carboxylase (ACCase). In the logarithmic phase acetyl-CoA might be used to synthesize other biomolecule (Huang et al. 2013). Secondly, lipid content was low in the logarithmic phase and the expression of accD was related with the content of lipid. Thus, the expression level of accD also appeared to be a good indicator of lipid content in the stationary phase of mixotrophic growth. However, the expression of accI was very low at all the levels, which suggested that accI might not be a key gene for lipid biosynthesis.

\section{ACKNOWLEDGEMENTS}

This work was financially supported by the research start-up costs of high- level personnel of the Qingdao Agricultural University (No.1114349) and the Natural Science Foundation of Shandong Province (No. ZR2011DL012).

\section{REFERENCES}

Chen F, Johns MR. Effect of $\mathrm{C} / \mathrm{N}$ ratio and aeration on the fatty acid composition of heterotrophic Chlorella sorokiniana. J Appl Phycol. 1991; 3: 203-209.

Cheng Y, Zhou WG, Gao CF, Lan K, Gao Y, Wu QY. Biodiesel production from Jerusalem artichoke (Helianthus tuberosus L.) tuber by heterotrophic microalgae Chlorella protothecoides. J Chem Technol Biotechnol. 2009; 84: 777-781.
Chisti Y. Biodiesel from microalgae. Biotechnol Adv. 2007; 25: 294-306.

Cronan JE, Waldrop GL. Multi-subunit acetyl-CoA carboxylases. Prog Lipid Res. 2002; 41: 407-435.

Huang XX, Huang ZZ, Wen W, Yan JQ. Effects of nitrogen supplementation of the culture medium on the growth, total lipid content and fatty acid profiles of three microalgae (Tetraselmis subcordiformis, Nannochloropsis oculata and Pavlova viridis). J Appl Phyco. 2013; 25: 129-137.

Li YQ, Horsman M, Wang B, Wu N, Lan CQ. Effects of nitrogen sources on cell growth and lipid accumulation of green alga Neochloris oleoabundans. Appl Microbiol Biotechnol. 2008; 81: 629-636.

Liang Y, Sarkany N, Cui Y. Biomass and lipid productivities of Chlorella vulgaris under autotrophic, heterotrophic and mixotrophic growth conditions. Biotechnol Lett. 2009; 31: 1043-1049.

Liu J, Yuan C, Hu GR, Li F. Effects of light intensity on the growth and lipid accumulation of microalga Scenedesmus sp. 11-1 under nitrogen limitation. Appl Biochem Biotechnol. 2012; 166: 2127-2137.

Nakkaew A, Chotigeat W, Eksomtramage T, Phongdara A. Cloning and expression of a plastid-encoded subunit, beta- carboxyltransferase gene (accD) and a nuclear-encoded subunit, biotin carboxylase of acetyl-CoA carboxylase from oil palm, (Elaeis guineensis Jacq). Plant Sci. 2008; 175: 497-504.

Sasaki Y, Nagano Y. Plant acetyl-CoA carboxylase: structure, biosynthesis, regulation, and gene manipulation for plant breeding. Biosci Biotechnol Biochem. 2004; 68: 1175-1184.

Sukenik A, Wahnon R. Biochemical quality of marine unicellular algae with special emphasis on lipid composition.I. Isochrysis galbana. Aquaculture. 1991; 97: 61-72.

Wan M, Liu P, Xia J, Rosenberg JN, Oyler GA, Betenbaugh MJ, et al. The effect of mixotrophy on microalgal growth, lipid content and expression levels of three pathway genes in Chlorella sorokiniana. Appl Microbiol Biotechnol. 2011; 91: 835-844.

$\mathrm{Xu}$ H, Miao XL, Wu QY. High quality biodiesel production from a microalga Chlorella protothecoides by heterotrophic growth in fermenters. J Biotechnol. 2006; 126: 499-507.

Received: October 08, 2014; Accepted: January 16, 2015. 